\title{
Plant Phenology in Galleta-Shadscale and Galleta-Sagebrush Associations
}

\author{
RICHARD L. EVERETT, PAUL T. TUELLER, J. BARRY DAVIS AND ALLEN D. BRUNNER
}

\begin{abstract}
Plant phenology is described for plant species in galleta grass (Hilaria jamesii)-shadescale (Atriplex confertifolia) and galleta grass-sagebrush (Artemisia tridentata ssp. wyomingensis) associations in Hot Creek and Reveille Valleys of Nevada. Species within both plant associations were separated into early, late, and indiscriminate flowering groups. Duration of the species phenology cycles varied from 72 days for Indian ricegrass (ryzopsis hymenoides) to 209 days for sagebrush. The phenological cycle of individual species varied as much as 62 days in length over a 4-year period. Phenology of species common to both galleta grassshadscale and galleta grass-sagebrush associations was similar in the same year. Differences in species phenology patterns are speculated to indicate different approaches to plant survival and species proliferation, but no one phenology pattern was obviously superior.
\end{abstract}

Understanding plant phenology is fundamental to understanding plant dynamics and to sound resource management of western United States shrublands. Plant phenology, the series of phases in plant development throughout the year (Lieth 1970), is an important morphological key to nutrient content (Robertson and Torrel 1958), carbohydrate reserves (Coyne and Cook 1970), and the growth rate of range species (Blaisdell 1958). Knowledge of plant phenology is useful in maximizing cattle gains and reducing detrimental grazing effects on plant species (Hormay 1970); and, in timing herbicide applications for maximum effectiveness in range restoration projects (Young and Evans 1974).

In the course of the study reported here the phenology of major plant species in galleta grass (Hilaria jamesii)shadscale (Atriplex confertifolia) and galleta grasssagebrush (Artemisia tridentata ssp. wyomingensis) plant associations were recorded. The study was conducted in the Great Basin from 1969 to 1972 . Species phenology among years, sites, and between plant associations were observed. Also, climate data were collected in 1972 to determine the causal mechanisms for major phenology changes (i.e., changes from vegetative to reproductive phases).

\section{Site Description}

Three study sites were selected inside cattle exclosures in the Hot Creek and Reveille Valleys. Exclosures occur within galleta grassshadescale (elevation $1.7 \mathrm{~km}$ ) and galleta grass-sagebrush (elevation $1.9 \mathrm{~km}$ ) associations approximately $1.2 \mathrm{~km}$ apart in Hot Creek Valley and in a galleta grass-shadscale association (elevation 1.8

Authors are respectively, range scientist, U.S. Dep. Agr. Forest Service, Intermountain Forest and Range Experiment Station, Ogden, Utah 84401; professor of range ecology, University of Nevada Reno; forester, U.S. Dep. Agr. Forest Service, Toiyabe National Forest, Bridgeport Ranger District, Bridgeport, California; and research associate, University of Nevada Reno.

All except J.B. Savis are located at the Renewable Natural Resources Center, University of Nevada Reno, Reno, Nevada 89512.

This article was written and prepared by U.S. Government employees on official time, and it is therefore in the public domain. Manuscript is a joint contribution of the participating agencies. Nevada Agriculture Experiment Station Journal Series No. 415.

Manuscript received April 30, 1979. $\overline{\mathrm{km}}$ ) approximately $55 \mathrm{~km}$ south in Reveille Valley. The soils have been previously described as Xerolic Haplargids, Typic Camborthids, and Typic Haplargids, respectively, by Tueller et al. (1972). All study sites have an east aspect and are on gently sloping terrain. The climate is arid with a mean annual precipitation of approximately $13.5 \mathrm{~cm}$.

\section{Methods}

Phenology of major plant species, galleta grass, shadscale, sagebrush, bud sagebrush (Artemisia spinescens), and rabbitbrush (Chrysothamnus viscidiflorus ssp. viscidiflorus) that characterize the vegetation of sites and associated minor species (spiny hopsage [Grayia spinosa], Indian ricegrass [Oryzopsis hymenoides], and globemallow [Sphaeralcea ambigua]) was recorded. Species phenology was recorded for 4 years (1969 to 1972) in both galleta grass-shadscale associations and for 2 years (1971 and 1972) in the galleta grass-sagebrush association. Plant phases used to describe the phenology of species are listed in Table 1.

Plants recorded were selected at random inside the exclosures. Grasses were sampled at the clonal or bunch level; shrubs were sampled as individual specimens. Phenology of 10 plants or clones of each of the major species was recorded. Each plant or clone was rated separately and assigned a numerical value based on its phenology stage as suggested by West and Wien (1971). The phenology stage assigned was based on the overall development of the reproductive culms or stems. The phenology stage dominant in each of the aforementioned associated minor species was also recorded for 1 to 10 plants of each species.

The same plants or clones were recorded at each measurement interval to eliminate genetic and topographic variations. Phenology phases of major species were photographed as a reference to improve repeatability of observations among years.

The frequency of measurement was determined by the rate of species development. In the months of rapid development, March, April, May, June, July, and August, development was recorded at weekly or biweekly intervals. In the remaining months, most species were in a semidormant or dormant condition and were measured at monthly intervals.

Precipitation and maximum-minimum air temperature $\left({ }^{\circ} \mathrm{C}\right)$ soil, water potential (-bars) and temperatures $\left({ }^{\circ} \mathrm{C}\right)$ at $30 \mathrm{~cm}$ soil depth were recorded concurrently with phenology during the 1972 growing season at study sites in Hot Creek Valley. Soil moisture and temperature were recorded with peltier psychrometers, air temperatures were recorded with maximum-minimum thermometers (in standard weather shelters), and precipitation was recorded with tipping-bucket recorders.

\section{Results}

Species show great variation in duration of the phenology cycle and in dates for breaking dormancy, seed dissemination, and summer senescence. Phenology cycle, the collection of sequential phenology stages occurring from initiation of growth to seed dissemination and/or plants drying, varied in length among species from a mean of 72 days for Indian ricegrass to 209 days for sagebrush (Table 2). Late flowering species had longer phenology cycles than 
Table 1. Plant phases and assigned numerical values used to describe development of each species.

\begin{tabular}{|c|c|c|c|c|c|}
\hline \multicolumn{2}{|c|}{ Grass species } & & & \multicolumn{2}{|c|}{ Shrub species ${ }^{1}$} \\
\hline \multirow{2}{*}{\multicolumn{2}{|c|}{$\begin{array}{l}\text { Galleta grass, } \\
\text { Indian ricegrass }\end{array}$}} & \multicolumn{2}{|c|}{ Forb species } & \multirow{2}{*}{\multicolumn{2}{|c|}{$\begin{array}{l}\text { Rabbitbrush, shadscale, hopsage, } \\
\text { sagebrush, bud sagebrush }\end{array}$}} \\
\hline & & & & & \\
\hline Stage & Value & Stage & Value & Stage & Value \\
\hline Dormancy & 0 & Dormancy & 0 & Dormancy & 0 \\
\hline Leaf growth & 10 & Leaf growth & 10 & Leaf growth & 10 \\
\hline Boot stage ${ }^{2}$ & 20 & $\begin{array}{l}\text { Stem growth } \\
\text { Flower buds }\end{array}$ & 20 & Twig growth & 20 \\
\hline Heads out & 30 & Flowering & 30 & $\begin{array}{l}\text { Flower stalk } \\
\text { Flower buds }\end{array}$ & 30 \\
\hline Anthesis & 40 & & & & \\
\hline Dough & 50 & Seed fill & 40 & Flowering & 40 \\
\hline Seed ripe & 60 & Seed ripe & 50 & $\begin{array}{l}\text { Seed fill } \\
\text { Seed ripe }\end{array}$ & $\begin{array}{l}50 \\
60\end{array}$ \\
\hline $\begin{array}{l}\text { Seed } \\
\text { dissemination }\end{array}$ & 70 & $\begin{array}{l}\text { Seed } \\
\text { dissemination } \\
\text { Perennial } \\
\text { basal leaves }\end{array}$ & $\begin{array}{l}60 \\
70\end{array}$ & $\begin{array}{l}\text { Seed } \\
\text { dissemination } \\
\text { Next year's leafbuds }\end{array}$ & $\begin{array}{l}70 \\
80\end{array}$ \\
\hline Senescence & 80 & Senescence & 80 & Senescence & 90 \\
\hline
\end{tabular}

'Specific phases are not present on all shrub species. Leaf fall is not included here as a plant phase because it may occur at any time water becomes limiting, but is shown in Figure 1 and 2 for the reader's information.

2Definitions of esoteric terms; Boot stage-florets within leaf sheath, heads out-florets out of leaf sheath, dough or seed fill-seed soft, seed ripe-seed hard.

earlier flowering species. Duration of an individual species phenology cycle varied as much as 62 days among years (Indian ricegrass, Table 2).

The mean date for breaking dormancy for all species lies between March 19 and April 7 (Table 2). However, there was a variation of as much as 49 days, among species in date of breaking dormancy, over a 4-year period. Large variability in date of breaking dormancy was also reported by Mueggler (1972) for mountain grassland species in Montana. No one species consistently broke dormancy before

Table 2. Mean and range in dates of breaking dormancy and day of active plant development by species and plant association. 1

\begin{tabular}{|c|c|c|c|c|}
\hline \multicolumn{3}{|c|}{ Date-breaking dormancy } & \multicolumn{2}{|c|}{$\begin{array}{c}\text { Days of active } \\
\text { development }\end{array}$} \\
\hline Species & Mean & Range & Mean & Range \\
\hline
\end{tabular}

Galleta grass

Rice grass

Globemallow

Shadscale

Bud sage

Galleta grass

Rice grass

Globemallow

Shadscale

Bud sage

Rabbitbrush

Hopsage
Galleta grass shadscale (Reveille Valley)

$\begin{array}{llrl}\text { April 7 } & 38 & 98^{2} & 40 \\ \text { March 31 } & 26 & 72 & 48 \\ \text { March 31 } & 23 & 81 & 18 \\ \text { March 26 } & 38 & 130 & 47 \\ \text { March 22 } & 30 & 86 & 32\end{array}$

Galleta grass-shadscale-(Hot Creek Valley)

April 6
April 2
March 26
March 28
March 24
March 24
March 19

$49 \quad 99$

$34 \quad 74$

$12 \quad 103$

$47 \quad 126$

$32 \quad 64$

$38 \quad 180$

$31 \quad 103$

$103 \quad 39$

Galleta grass-sagebrush-(Hot Creek Valley)
Galleta grass

Rice grass

Globemallow

Rabbitbrush

Sagebrush

Hopsage

March 24
April 7
March 27
March 18
March 24
March 24

$46 \quad 110$

$20 \quad 74$

$6 \quad 86$

$33 \quad 174$

$46 \quad 209$

$46 \quad 82$ the others, and in any given year all species broke dormancy within a 30-day period.

Individual phenology phases in all species compressed or expanded in different years in response to varying environmental conditions. With the exception of spiny hopsage, shrub vegetative phases were compressed and reproductive phases expanded in 1971 as compared to 1972 as indicated in the relative duration of vegetative and reproductive phases in Figures 1 and 2. As the same plants were measured every year, these differences in phenology phases are considered the result of differences in climate, notably temperature and moisture-factors of major importance in plant phenology

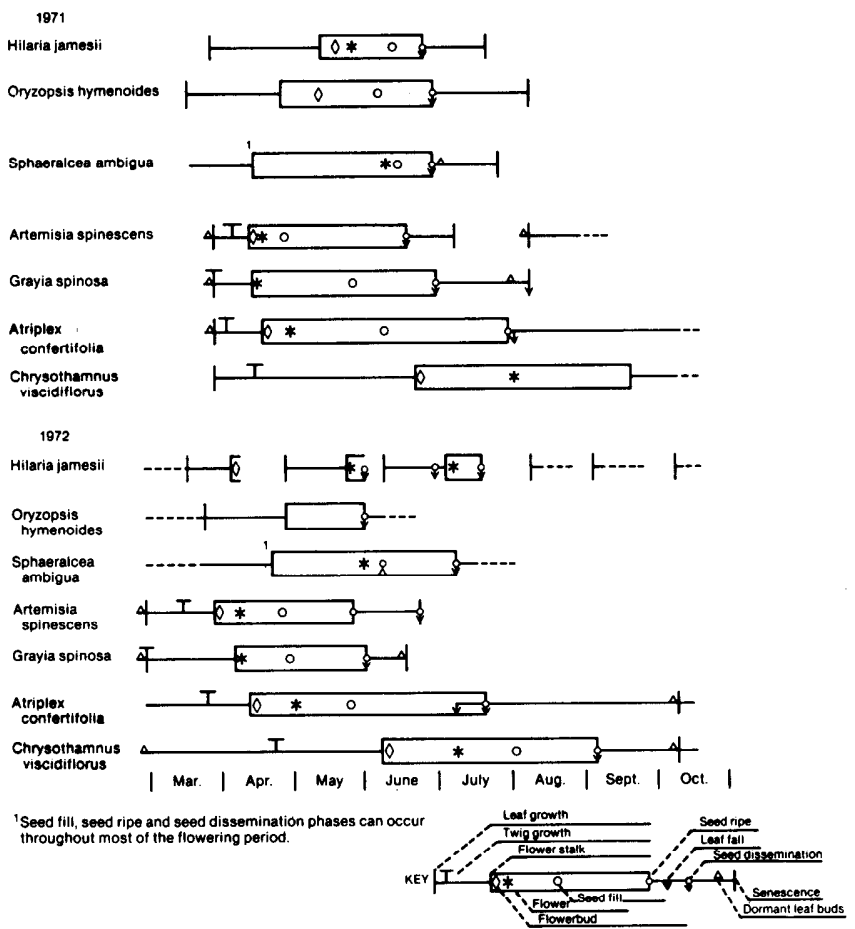

Fig. 1. Phenology of species in galleta grass-shadscale association in Hot Creek Valley (1971-1972). Missing phenology stage symbols do not indicate nonoccurrence, but only our failure to observe the stage in the field.
'We define active plant development as those phases that require mois
tion (i.e., all phases up to and including seed ripe, except leaf fall)

${ }^{2}$ Active development in days. 


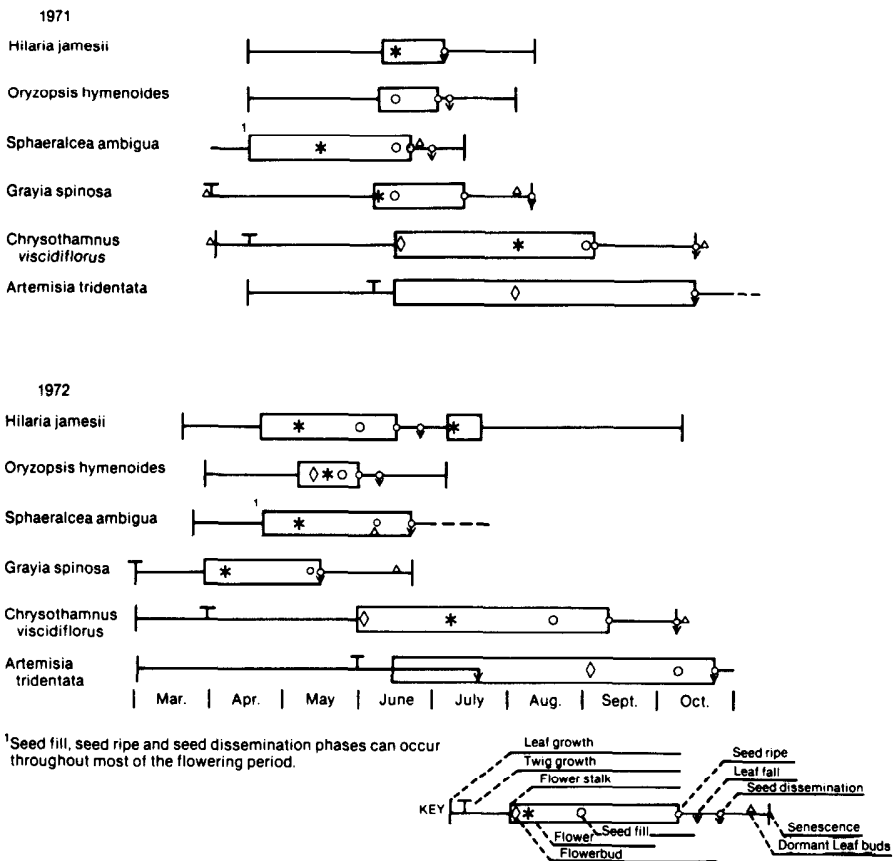

Fig. 2. Phenology of species in a galleta grass-sagebrush association in Hot Creek Valley (1971-1972).

of Mohave Desert species to the south (Ackerman and Bamberg 1974). West and Gastro (1978) previously reported changes in the length of species phenology stages among years for cold desert species in Utah linking these changes to differences in moisture and temperature.

The phenology of a species in the galleta grass-shadscale association of Hot Creek Valley was similar to its phenology in galleta grass-sagebrush association in the same valley (Fig. 3) and in the galleta grass-shadscale association of Reveille Valley $55 \mathrm{~km}$ distant (Fig. 4). Although phenology of a species was consistent between shadscale and sagebrush associations, flowering date for the species (i.e., rabbitbrush) may be ahead or behind that of dominant shrubs (Fig. 1 and 2).

Yearling variations in macroclimate control initiation of species phenology and affect its general pattern (Fig. 3 and

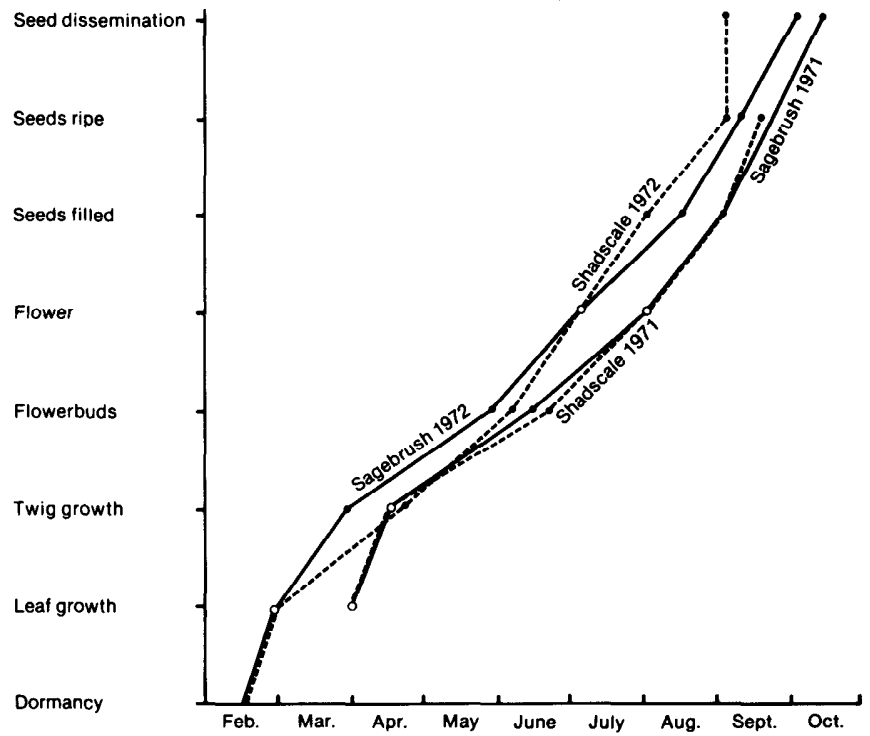

Fig. 3. Phenology of rabbitbrush in galleta grass-shadscale and galleta grass-sagebrush associations in Hot Creek Valley (1971-1972).

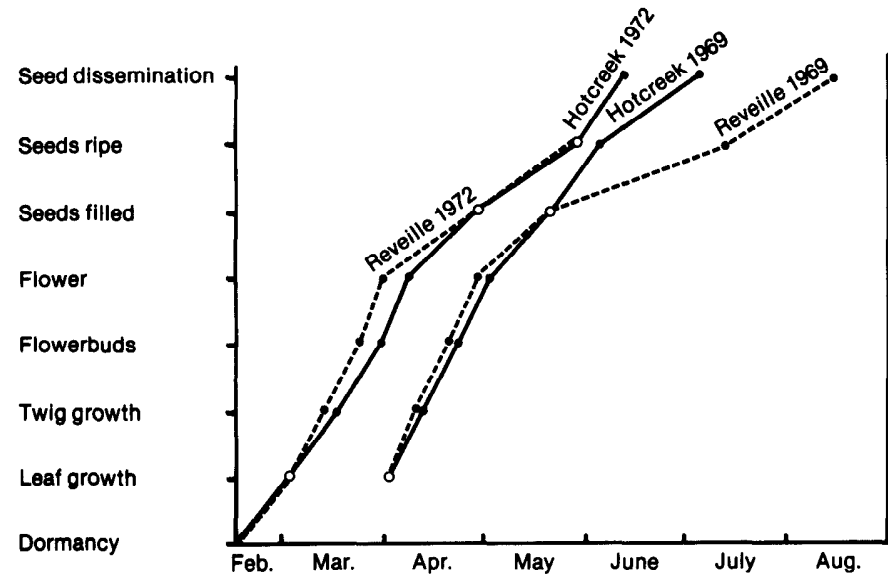

Fig. 4. Phenology of shadscale in Hot Creek and Reveille Valley $(55 \mathrm{~km}$ apart) (1969-1972).

4). Microsite or ecotype effects on phenology can be seen in the divergence of the graphed phenology patterns for species on different sites in the same year (Fig. 5). The complete interruption of 1972 galleta grass phenology in the galleta grass-shadscale association (Fig. 1) demonstrates the degree to which microclimate can alter plant phenology.

Galleta grass initiated more than one phenology cycle during the growing season if summer precipitation allowed. After summer rains, in 1972, galleta grass started several phenology cycles in the galleta grass-shadescale association (Figure 1). Seed heads were put up several times only to have the unripened seed stripped off by the wind and rain in the following storm. This phenomenon was not apparent within the adjacent galleta grass-sagebrush association (Fig. 2).

Bud sagebrush and grazed globemallow plants (outside the exclosures) also initiated new phenology cycles following summer precipitation, but this was limited to leaf growth in bud sagebrush. Spiny hopsage like bud sagebrush entered summer dormancy early but did not initiate new leaves following summer precipitation. A cold requirement has to be met before summer dormant spiny hopsage can initiate new growth (Wallace and Romney 1974).

All shrubs except sagebrush were observed to initiate next

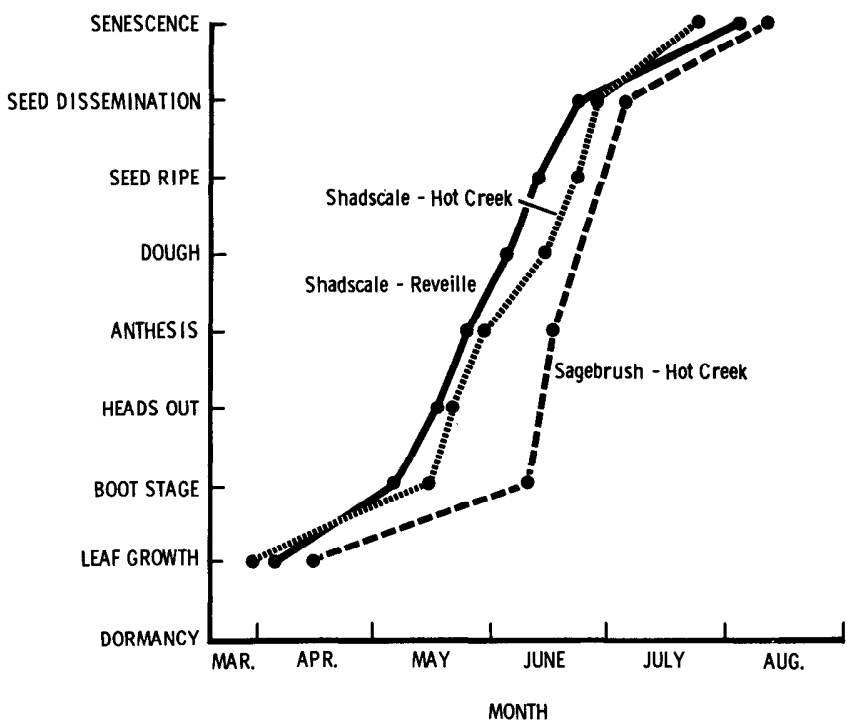

Fig. 5. 1971 phenology of galleta grass in grass-shadscale associations of Hot Creek and Reveille Valleys and in the galleta grass-sagebrush association of Hot Creek Valley. 
year's leaf buds before the end of the current phenology cycle. The absence of winter buds on sagebrush has been previously reported by Morton and Hull (1973). Shadscale produced swirls of smaller leaves on vegetative stems and globemallow initiated perennial basal leaves during summer as reported by Moore, et al. (1972) and Beatley (1974), respectively.

Magnitude and time of leaf drop varied among shrub species studied. Summer deciduous species, bud sagebrush and spiny hopsage rapidly complete their phenology cycles in early summer then drop a majority of their leaves and go into senescence or dormancy as soil moisture declines and temperatures (soil and air) increase (Fig. 6 and 7). Species with both perennial and ephemeral leaves, sagebrush and shadscale, drop a portion of their leaves during summer drought as previously described by Campbell and Harris (1977) and Moore, et al. (1972), respectively. At this time succulent stems of shadscale become brittle, forming sharp spines. Rabbitbrush (winter deciduous) was unique in that no leaf drop was observed during summer drought.

Many species in the associations initiate vegetative growth under cool, moist conditions and complete seed production under conditions of decreasing soil moisture and rising temperatures (June-July) (Fig. 6 and 7). Sagebrush and rabbitbrush, however, complete seed production as soil moisture increases and air and soil temperatures decline (in late summer or fall, September-October). Galleta grass was capable of vegetative and reproductive phases under an array of environmental conditions.

\section{Discussion}

Dates for initiation of growth, seed dissemination, and plant senescence vary considerably among years indicating the impracticality of preset calendar dates for integrating grazing management to current range conditions. West and Gastro (1978) suggested phenology dates as a biological index and a more appropriate alternative. Phenology's usefulness as a biological index is, however, limited by our ability to measure plant phenology and interpret its significance. Overlapping phenology stages on the same plant, simultaneous occurrence of different phenology stages on

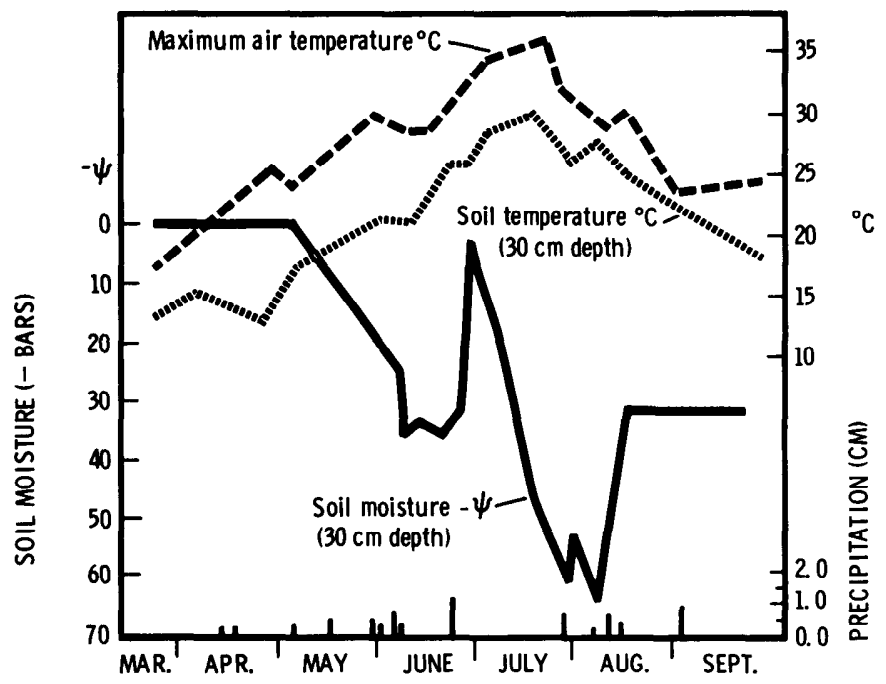

Fig. 6. Trends in air and soil temperature $(C$ ) and soil moisture during the 1972 growing season in galleta grass-shadscale association in Hot Creek Valley.

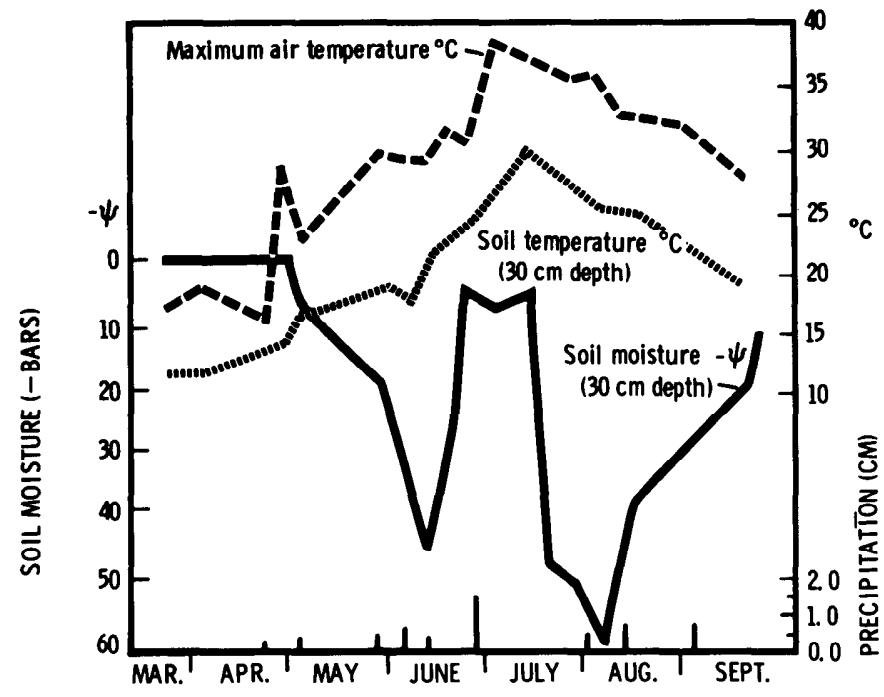

Fig. 7. Trends in air and soil temperature $\left({ }^{\circ}\right.$ ) and soil moisture during the 1972 growing season in galleta grass-sagebrush association in Hot Creek Valley.

plants of the same species, and different phenology patterns among species within an association make interpretation of a phenology rating for a single species more complex.

Because of the variability in phenology among species, more than one species must be observed to follow phenology (i.e., breaking dormancy) of the plant association as a whole. Separating species into flowering groups simplifies this observation task.

Species in galleta grass-shadscale and galleta grasssagebrush associations can be separated into early, late, and indiscriminate flowering groups. Early flowering species (shadscale, spiny hopsage, bud sagebrush, and Indian ricegrass) flower before summer drought (July-August) (Fig. I and 2). Late flowering species (rabbitbrush and sagebrush) flower during or after the drought period. Galleta grass and globemallow flower indiscriminately over a period of several weeks. Observing one species from each flowering group would appear necessary to characterize phenology for the plant association as a whole as suggested by Dickinson and Dodd (1976).

This procedure is an oversimplification and it is not implied that one species can be used to predict the phenology of all species within a flowering group. Species respond to changes in the environment in a dissimilar manner and to different degrees as seen in the variation among species phenology in 1971 and 1972. The contraction and expansion of phenology phases and the unpredictability of precipitation and temperature, major factors controlling phenology of desert species (Ackerman and Bamberg 1974), would confound attempts to accurately predict phenology of one species from another.

As dominance within associations is shared among species having different phenology patterns, no one pattern is obviously superior for species survival as Blaisdell (1958) suggested for the sagebrush-grass type. It was beyond the scope of this study to determine any advantage one species may have over another because of differences in phenology pattern but variations in phenology patterns lead us to speculate that species differ in their survival and reproductive strategies.

One of the common plant adaptations to reduce water loss during summer drought is leaf drop. Total leaf drop by 
bud sagebrush and spiny hopsage indicate maximum use of this adaptation, less so for sagebrush and shadscale which retain smaller permanent leaves and drop the larger ephemerals. Rabbitbrush does not drop leaves during summer drought and must depend upon other adaptations such as resinous leaves with increased light reflectance to survive drought conditions (Anderson 1975).

Early flowering species depend upon spring moisture for both vegetative growth and seed production. Late flowering species utilize spring moisture for vegetative growth and split a portion of the reproductive phases between available soil moisture in the spring and fall. Reduced probability of seed production of late flowering species has been suggested by Sauer and Uresk (1976) for steppe plants and Ackerman and Bamberg (1972) for plants of the Mohave Desert, but seed production of early flowering species such as shadscale is also variable under arid conditions (West and Gastro 1978). Seeds disseminated during summer drought on these sites would appear to enter an environment less suitable for seedling germination and establishment than fall disseminated seed. Differences in approach to drought avoidance and reproductive strategies are indicated by phenology patterns but phenology provides little information as to why they occur.

\section{Conclusion}

Phenology is a biological index by which grazing management can be integrated to current range conditions but phenology ratings are less than absolute. The simultaneous occurrence of different phenology stages on the same plant, plants of the same species concurrently in different phenology stages, and different phenology patterns among associated species increases the complexity of interpreting a phenology rating for a single species. Recognizing these limitations, phenology remains a valuable tool in illuminating potential relationships between plants and plants and their environment.

Major species in galleta grass-shadscale and galleta grasssagebrush associations can be separated into early, late, and indiscriminate flowering groups. Observing at least one species in each flowering group appears necessary to characterize the phenology of the association as a whole. However, this is at best an oversimplification of the phenology patterns present. Accurate prediction of one species'phenology from another would appear difficult because of the expansion or contraction of individual phenology phases among years.

Phenology was similar in species common to the two galleta grass-shadscale associations $55 \mathrm{~km}$ apart or in galleta grass-shadscale and galleta grass-sagebrush associations in Hot Creek Valley. Macroclimate controlled initiation of species phenology and combined with microsite and ecotype effects to alter species phenology among years.

We speculate that variation in the amount and timing of leaf drop by shrub species and the variability in periods of flowering suggests species have alternative strategies toward plant survival and reproduction. As major species within both galleta grass-shadscale and galleta grass-sagebrush associations differ widely in phenology patterns, no one pattern is obviously superior.

\section{Literature Cited}

Ackerman, T.L., and S.A. Bamberg. 1974. Phenology studies in the Mohave Desert at Rock Valley (Nevada test site). p. 215-226. In: H. Lieth (ed.), Phenology and Seasonality Modeling. Springer-Verlag, New York.

Anderson, L.C. 1975. Modes of adaptation to desert conditions in Chrysothamnus. p. 141. In: H.C. Stutz (ed.), Proceedings, symposium and workshop, wildland shrubs. Brigham Young Univ., Provo, Utah.

Beatley, J.C. 1974. Phenology events and their environmental triggers in Mohave Desert ecosystems. Ecology 55: 856-863.

Blaisdell, J.P. 1958. Seasonal development and yield of native plants on the upper Snake River Plains and their relation to certain climatic factors. U.S. Dep. Agr. Tech. Bull. 1190: 1-82.

Campbell, G.S., and G.A. Harris. 1977. Water relations and water use patterns for Artemisia tridentata Nutt. in wet and dry years. Ecology 58: 652-659.

Coyne, P.J., and W.C. Cook. 1970. Seasonal carbohydrate cycles in eight desert range species. J. Range Manage. 23: 438-444.

Dickinson, C.E., and J.L. Dodd. 1976. Phenology pattern in the shortgrass prairie. Amer. Midl. Natur. 96: 367-378.

Hormay, A.L. 1970. Principles of rest-rotation grazing and multiple-use land management. U.S. Dep. Inter. and U.S. Dep. Agr. 26 p.

Lieth, H. 1970. Phenology in productivity studies. p. 29. In: R. Reichle (ed.), Analysis of Temperate Forest Ecosystems. Springer-Verlag, Heidelberg.

Moore, R.T., R.S. White, and M.M. Caldwell. 1972. Transpiration of Atriplex confertifolia and Eurotia lanata in relation to soil, plants, and atmospheric moisture stress. Can. J. Bot. 50: 2411-2418.

Morton, H.L., and H.M. Hull. 1973. Morphology and phenology of desert shrubs. p. 39-46. In: D.N. Huder (ed.), Arid shrublands-proceedings of the third workshop of the United States/Australia rangelands panel, Tucson, Arizona, March 26-April 5.

Mueggler, W.F. 1972. Plant development and yield on mountain grasslands in southwestern Montana. U.S. Dep. Agr., Forest Serv. Res. Pap. INT-124, 20 p. Intermtn. Forest and Range Exp. Sta., Ogden, Utah.

Robertson, J.H., and C. Torrel. 1958. Phenology as related to chemical composition of plants and to cattle gains on summer ranges in Nevada. Univ. Nevada Agr. Exp. Sta. Bull 197: 1-38.

Sauer, R.H., and D.W. Uresk. 1976. Phenology of steppe plants in wet and dry years. Northwest Sci. 50: 1-8.

Tueller, P.T., A.D. Brunner, and J.B. Davis. 1972. Ecology of Hot Creek Valley-vegetation and soil response to underground detonation. Univ. Nevada Agr. Exp. Sta. NVO-409-1: 1-131.

Wallace, A., and E.M. Romney. 1972. Radioecology and ecophysiology of desert plants at the Nevada test sites. U.S. Atomic Energy Comm. TID-25954. $439 \mathrm{p}$.

West, N.E., and J. Gastro. 1978. Phenology of the aerial portions of shadscale and winterfat in Curlew Valley, Utah. J. Range Manage. 31: 43-45.

West, N.E., and R.W. Wein. 1971. A plant phenological index technique. BioSci. 20: 116-117.

Young, J.A., and R.A. Evans. 1974.Phenology of Chrysothamnus viscidiflorus subspecies viscidiflorus (Hook.) Huft. Weed Sci. 22: 469-475. 